Article

\title{
Experiencing Nature: Physical Activity, Beauty and Tension in Tatra National Park-Analysis of TripAdvisor Reviews
}

\author{
Agnieszka Niezgoda ${ }^{1}$ and Marek Nowacki ${ }^{2, *(1)}$ \\ 1 Department of International Economics, Poznań University of Economics and Business, aleja Niepodległości \\ 10, 61-875 Poznań, Poland; agnieszka.niezgoda@ue.poznan.pl \\ 2 Department of Socio-Economics, WSB University in Poznań, Powstańców Wielkopolskich 5, \\ 61-874 Poznań, Poland \\ * Correspondence: marek.nowacki@wsb.poznan.pl; Tel.: +48-61-655-33-33
}

Received: 30 November 2019; Accepted: 11 January 2020; Published: 14 January 2020

\begin{abstract}
The aim of this article is to analyse the experiences gained by tourists visiting one of the most visited protected areas in Poland-the Tatra National Park (TNP). The authors focused on the following question: does the natural heritage of the national park affect visitors' unique experiences or is environmentally valuable area not important for their experiences? This article uses mixed quantitative (Text Mining, co-occurrence network analysis) and qualitative (narratives research) methods. Data for analysis-revives posted by users between April 2011 and September 2019-were downloaded from TripAdvisor.co.uk. Reviews on TripAdvisor indicate that the most important for visiting tourists were the experiences of physical activity. This confirms the trend of maintaining health and the desire to regenerate physical strength. The group of reviews related to connection to nature experiences is extremely small, which indicates that tourists probably did not come to TNP as a result of a preference for experiences related to ecological awareness. Some tourists felt tension, which indicates that the carrying capacity was exceeded. There is a doubt as to whether tourists who want to engage in physical activity must necessarily visit the area with the highest degree of nature protection.
\end{abstract}

Keywords: tourist experiences; ecological awareness; protected areas; Tatra National Park; TripAdvisor

\section{Introduction}

The decision-making process in tourism is complex and includes choices regarding both travel destination, services and attractions [1] (pp. 53-54). Many different, often interdependent factors influence consumers' decisions. Along with the increase in purchasing funds, the scope of consumer decisions is expanding, and psychological and social factors have a greater impact on decisions [2,3]. These factors include experience preferences, including those related to relaxation in natural areas.

The need for new experiences while traveling is becoming more and more common [1,4-7]. The fact that participation in tourism is no longer reserved for privileged social classes means that some tourists no longer want to participate in ready-made tours and take advantage of banal offers. They want to give meaning to their travels and are looking for elite forms of rest in which experience can play a distinctive role. In response to changes in tourism demand on the tourism supply side, a shift from service-oriented economy to experience economy can be seen [8]. Experiences can be the basis for creating a product regardless of the restrictions of mass tourism [9] (p. 10).

The aim of this article was to analyse the experiences gained by tourists visiting one of the most visited protected areas in Poland—the Tatra National Park (TNP). The authors focused on the 
following question: does the natural heritage of the national park affect visitors' unique experiences or is environmentally valuable area not important for their experiences?

It was assumed that tourists who visit TNP voluntarily post on TripAdvisor an opinion reflecting their impressions and experience about their visit [10]. What is credible to them is what has been verified in person or by other objective consumers [11]. The Authors agree with Sue Beeton, Heather E. Bowen and Carla Almeida Santos, who outlined the notion of social construction and mass media's powerful role in constructing tourism and tourist experiences. [12] (p. 34).

Richard Butler noted that contemporary volatile demand in tourism does not always mean that tourists are sophisticated, considerate, environmentally and culturally sympathetic, affluent and discerning visitors, which many destinations aspire for [13] (p. 18). The results of the current research will show whether tourists visiting one of the most crowded and at the same time, the most attractive areas in Poland, show behavior consistent with the idea of ecological awareness.

\subsection{Experience Preferences and Ecological Awareness}

The problem of experience gained by visitors of natural areas has been the subject of research in the field of outdoor recreation for many years. This is the so-called "experiential approach", which is one of the lines of leisure motivational research [14]. The experiential approach suggests that recreation is not only an activity (like hiking or fishing) but is a psychophysiological self-rewarding experience [15]. Four levels of demands for outdoor recreation were identified, of which level 4 refers to the higher-order benefits that can flow from satisfying experiences derived from recreation participation [16] (p. 159).

It can be argued that the desire for experiences is also an important motivation for tourist trips. Authenticity, existential authenticity, sincerity, hyperreality and simulacra are overlapping concepts often used in accounting for the tourist experience [17].

Experiences are understood as the knowledge or feeling obtained through direct impressions [18]. According to Erik Cohen [19] tourist experiences refer to a quest for strangeness while Carmen Antón et al. [20] (p. 2) emphasized that experience is something that goes beyond everyday life, becomes unforgettable and contributes to the personal enrichment of the person who experiences it. Jianyu Ma, Jun Gao and Noel Scott [21] (p. 5) stated that experiences have four attributes: subjectivity, commitment, emotions and learning. Kathleen Andereck, Kelly S. Bricker, Deborah Kerstetter and Norma Polovitz Nickerson stated that an experience is not a snapshot, but rather a complex process that involves multiple parties, evolves over time, and retains value long into the future [22] (p. 82).

Tourists still expect new information from the world. Dean MacCannel [4] stated that being a tourist entails a certain way of spending free time by collecting impressions. Chris Ryan [1] added that a greater frequency of positive experiences generates higher scores on measures of well-being and satisfaction with life, although the intensity of the experiences seems to add little to the total score. In the end, people buy total experiences that products or services provide. That is why experience management, understood as a way to remain competitive in markets where globalization and technology have turned products and services into commodities, plays a very important role [23].

A tourist is looking for new experiences and these can only be provided by what he has not seen, or at least something that is different from everyday life. People may also perceive travel as a means of escape after encountering personal troubles or failures with the gained travel experience [24,25]. Protected areas are places where tourists can experience this difference. The scenery provides a quality experience for them, often because it is different from what they have at home. In addition, the natural environment is the conduit for spiritual connection, which, in turn, provides quality tourism experiences. [26] (p. 230). National parks came into being with the more noble and inspiring purpose to protect areas of wild lands for a nation rather than for a privileged few, and at the same time, encourage access to those areas by all those who can travel there [27].

The purpose of creating areas with a high degree of protection is to preserve the ecosystem in accordance with ecological objectives. If there were no paradox that tourism destroys the object of its desire [28] (p. 868), the condition would be the ecological awareness of tourists, which 
takes into account not only the process of "raising awareness" but also the effects of this process. According to this definition, environmental awareness is the awareness of people's dependence on the rest of nature and the awareness of the impact that human activities have on the surrounding environment [29]. Ecotourism plays an important role because "ecotourism experiences enhance environmental knowledge, which is a key component in the transformation of environmental attitudes and the development of an environmental consciousness that could result in changed environmental behaviors" [30] (p. 146).

Improper behavior of tourists in relation to the environment cause its destruction. This occurs both through a lack of ecological awareness, as well as through the lack of implementation of ecological behavior despite knowledge of the problem. As Brendan Canavan noted [31], despite the growing environmental awareness, leisure is still a hedonistic experience for many tourists, far from being responsible. David Fennel [32] noted, however, that not all types of nature tourists are necessarily compatible with the environment. Therefore, one should firstly consider the experience preferences under which tourists come to protected areas and secondly, whether tourists' behavior is related to environmental awareness. The answer to these questions can be found by analyzing the experiences of tourists visiting natural areas.

\subsection{Tourist Experiences in Natural Areas}

An important trend characteristic of modern tourists is "return to nature". This includes the desire for experiencing tranquility, viewing scenery, as well as keeping physically healthy surrounded by soothing nature [33-35].

Susanna Curtin and Gitte Kragh [36] argued that the experience of urbanization and detachment from the nature of modern man prompts him to experience nature and contact with animals. The authors pointed to a number of benefits resulting from human being surrounded by trees and natural landscape. These include relaxation, less anxiety, lack of anger and depression. Being in nature and admiring animal behavior provides a sense of flow [37], a peak experience [38] and a sense of connection with nature [39]. There are also reports about forest therapy that considered a therapeutic method of rapidly growing popularity [40-42]. Mike Peters, Klaus Weiermair, Phunthumadee Katawandee [5] mentioned experience of nature, peace and quiet, relaxation, seclusion, among other dimensions of the destination product.

Jennifer Hill, Susanna Curtin and Georgie Gough [43] identified a number of experiences of embodied encounters with nature. These include sensory interaction (visitors articulated an ecological gaze), affective/emotional response which was manifested in five oppositions: wonder and awe, empathy/anthropomorphism, immersion versus alienation, security versus vulnerability and calm versus excited.

Jan Packer and Roy Ballantyne [44] reviewed the understanding of the concept of nature experience. They identified ten groups of visitor experiences: physical (i.e., movement, action, physical stimulation), sensory (perceptual, aesthetic, sensory responses to surroundings), restorative (escape, relaxation, revitalization), introspective (contemplation, imagination, reflection), transformative (inspiration, capability, mastery), hedonic (excitement, enjoyment, fun), emotional (surprise, respect, joy), relational (social interactions, belonging), spiritual (transcendence, connection with sacred, communion with nature) and cognitive (intellectual, learning, novelty).

Analyzing reviews taken from TripAdvisor and using the dimensions of experiences identified by Jan Packer and Roy Ballantyne [44], Oana Stoleriua et al. [45] analysed the experiences of people visiting the Danube Delta. Analyzing reviews from TripAdvisor, Oana Stoleriua et al. [45] identified four groups of nature experiences: sensory experiences, awe and wonder or emotional experiences, cognitive (reflective) experiences and spatiotemporal experiences.

Thus, one can notice the simultaneous occurrence of the trend of seeking solace in nature and the search for experiences by modern tourists. The condition of a tourist trip fulfilling this assumption is a destination with a high degree of conservation of natural values. In Poland, these include protected 
areas, among which National Parks are the highest form of protection. One of the most famous and most visited national parks in Poland is the Tatra National Park [46] (p. 25).

\subsection{Tatra National Park-Characteristics of the Area}

Tatra National Park is the most famous tourism destination among national parks in Poland. In the nineteenth century, the area of the Tatra Mountains was a very fashionable place where well known painters, writers and poets rested. Already in this period, the influx of tourists caused activities for the protection of nature. In 1873, the Tatra Society (the first tourist organization in Poland) was founded to bring together scientists and people from the world of science and politics. In this group, the idea of creating a National Park in the Tatra Mountains arose, which was realized only after World War II in 1954 [47] (pp. 22-23). Tatra National Park covers an area of 211,000 square kilometers and in this respect, is one of the largest among 23 national parks in Poland. The Park is a natural habitat of endemic animal species, such as the Tatra chamois, marmot, bear, lynx, wildcat and wolf. TNP borders cover the entire area of the Polish part of the Tatra Mountains and nearly 3700 ha of adjacent forest complexes. Approximately 70\% of the Park area is occupied by forests and thickets of mountain pine, and about 30\%-alpine grasslands, rocks and waters. Nearly 12.3 thousand ha of TNP area are strictly protected areas. They are excluded from the economy and human interference. Due to its attractiveness and history of tourist traffic, TNP belongs to the most crowded protected areas in Poland [46] (p. 25). Yet, its Alpine character and rich landscape attract a record number of tourists each year - according to TNP data, this amounts to 4 million tourists annually [48].

\section{Materials and Methods}

Data for analysis were downloaded from the English-language TripAdvisor site [49]. It is the world's largest aggregator of reviews of tourist products visited monthly by 490 million users. It contains 760 million reviews and opinions of 8.3 million accommodations, restaurants, attractions and excursions, airlines and cruises. TripAdvisor operates in 49 markets in 28 languages [50]. With the help of the Web Scrapper package [51], all opinions from the 'Things to do' category were collected regarding places located in the Tatra National Park (attractions that had at least 10 reviews). In total, they were 624 reviews in 10 categories: 2 mountain ponds, 3 valleys, 2 peaks, 2 waterfalls and the Tatra Mountains as a whole (Table 1). The oldest opinion was from April 2011 and the latest from September 2019. The number of experiences by reviewers was very high. The average number of reviews written by one person was 155.24, and the median was 41 . The average number of likes received by one person was 72.82 and the median was 21 . The maximum number of reviews about TNP made by one person was 6 , with an average of 1.70 .

Table 1. Distribution of opinions regarding the 'Things to do' category for Tatra National Park.

\begin{tabular}{ccccc}
\hline Place & N & \% & Mean Traveler Rating & Standard Deviation \\
\hline Morskie Oko (lake) & 344 & 55.128 & 4.542 & 0.891 \\
Koscielisko Valley & 17 & 2.724 & 4.411 & 0.507 \\
Black Pond & 51 & 8.173 & 4.450 & 0.944 \\
Rysy (Mt.) & 24 & 3.846 & 4.916 & 0.282 \\
Chocholowska Valley & 11 & 1.763 & 4.363 & 1.206 \\
Mickiewicz Waterfall & 16 & 2.564 & 3.562 & 1.152 \\
Giewont (Mt.) & 77 & 12.340 & 4.506 & 0.788 \\
Strazyska Valley & 10 & 1.603 & 4.800 & 0.421 \\
Tatra (range) & 64 & 10.256 & 4.734 & 0.597 \\
Siklawica Waterfall & 10 & 1.603 & 4.111 & 1.054 \\
SUM & 624 & 100 & 4.530 & 0.862 \\
\hline
\end{tabular}

A number of software packages were used in the data analysis. The Statistica 13.0 package was used for a Text Mining analysis. Tag clouds were made with the QSR NVivo Pro 11.0 package. 
Grouping of words (co-occurrence analysis) and coding of experiences were performed using the $\mathrm{KH}$ Coder package.

\section{Results}

This section is divided by subheadings. It provides a concise and precise description of the experimental results, their interpretation as well as the experimental conclusions that can be drawn.

\subsection{Identifying the Most Common Words in Reviews}

In the first stage of the analysis, in order to identify the most common words in opinions, the Text Mining procedure was performed. It consists in counting the most frequently repeated words. The analysis used the list EnglishStopList.txt ("a", "the", "and" etc.) for words which were omitted in the analysis. A procedure of lemmatization was also performed, which involves grouping inflected forms of words to the dictionary form. In this way, different grammatical forms of the same word were combined into one category. Thus, 149 words were obtained, which appeared in at least $1 \%$ (62) of opinions. Table 2 presents the 52 most frequently repeated words in the reviews, and Figure 1 illustrates them in the form of a tag cloud.

Table 2. List of the 52 most frequent words in reviews.

\begin{tabular}{cccccccc}
\hline Words & TF & Words & TF & Words & TF & Words & TF \\
\hline lake & 807 & mountains & 236 & view & 172 & carriage & 131 \\
walk & 660 & hike & 235 & see & 169 & nice & 128 \\
take & 318 & views & 231 & back & 165 & easy & 127 \\
way & 305 & worth & 223 & bus & 162 & well & 126 \\
beautiful & 304 & mountain & 220 & road & 161 & visit & 117 \\
oko & 292 & day & 217 & took & 159 & tatra & 111 \\
get & 285 & people & 217 & trip & 152 & like & 108 \\
around & 276 & park & 201 & walking & 152 & car & 107 \\
horse & 267 & good & 198 & long & 151 & hour & 107 \\
morskie & 265 & time & 195 & just & 150 & early & 105 \\
zakopane & 254 & hours & 184 & amazing & 145 & climb & 104 \\
place & 252 & top & 179 & also & 133 & trail & 104 \\
one & 247 & great & 174 & really & 132 & many & 103 \\
\hline
\end{tabular}

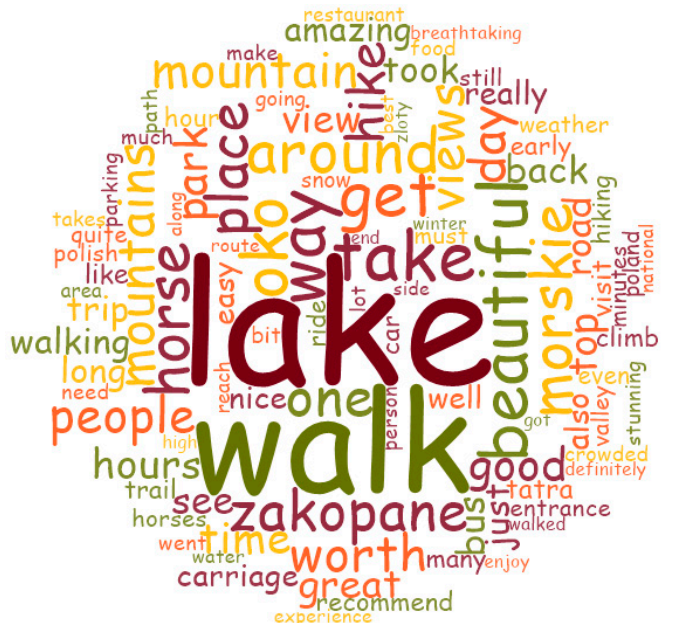

Figure 1. The cloud of tags for Tatra National Park reviews (source: own research).

\subsection{Identification of the Most Common Problems in Opinions-Quality Analysis}

In order to identify the problems most frequently appearing in opinions, a co-occurrence network analysis using the KH Coder package was performed. The analysis took into account 124 most frequently repeated words in opinions that appeared in at least $1 \%$ of opinions. 
The co-occurrence network of words analysis allows to plot a network of relationships between words with a high degree of co-occurrence. These words were connected with each other by lines (Figure 2). In order to determine the mutual position of words, the co-occurrence network of words uses a method developed by Thomas Fruchterman and Edward Reingold [52]. Words being close together does not always mean that they often occur together. It is important that these words are connected with each other by lines. As a result of the analysis, 5 groups of words co-existed simultaneously in the analyzed opinions.

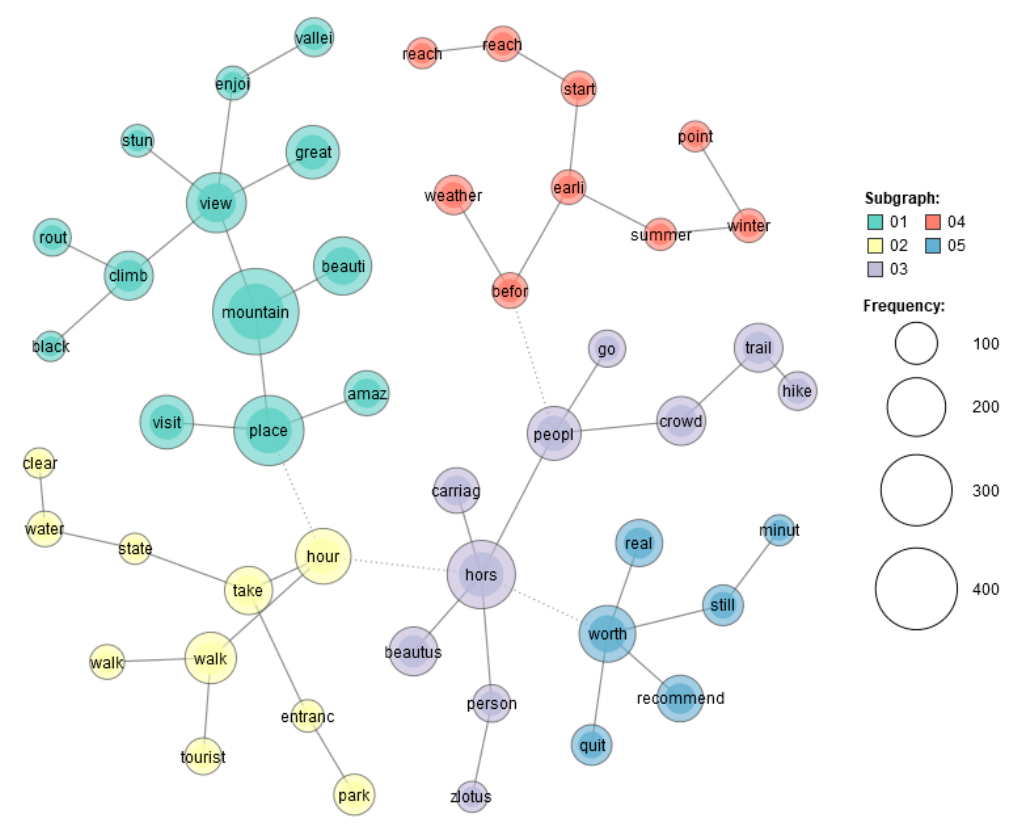

Figure 2. Co-occurrence network of frequently occurring words (source: own research).

The five most recurring problems are discussed below, with some examples of opinions.

The first group of opinions contains words such as mountain, place, view, great, climb, place visit, amaz (ing). It relates to sensory experiences related to mountains appearing during climbing and visiting unusual places in the Tatra.

It was really amazing trip to this beautiful place (...), adorable place (...) you will see this breath-taking view! The Lake with crystal pure blue-green water, surrounded by mountains, like dream or fantasy. (Nastya_Lampy, St. Petersburg, Russia, 5 *)—Morskie Oko (lake)

Morskie Oko is one of the main destinations for trips in the Tatra Mountains. It is the largest lake in the Tatra (area 34.94 ha), of postglacial origin, located in the Valley of the Rybi Potok at an altitude of $1395 \mathrm{~m}$ a.s.l. at the foot of Mieguszowieckie Szczyty (2435 m a.s.l.). This location determines the unique landscape that surrounds it. The lake is relatively easily accessible because an asphalt road that leads to it from a car park $(8.5 \mathrm{~km})$, which can be covered on foot or on bulls pulled by horses.

One of the most incredible places I had seen on the planet. Beautiful mountains, amazing lakes and everything in an easy access. (Sara P, Barbacena, MG, 5 *)_Tatra Mountains

The Chocholowska Valley (Dolina Chochołowska), with a tourist chalet (schronisko) located at its end, is the second place that sees a huge interest of tourists in TNP. It is the longest and largest valley in the Tatra (approx. $35 \mathrm{~km}^{2}, 10 \mathrm{~km}$ long). You can get to the chalet on foot or in a highlander carriage. The valley is surrounded by a number of peaks, including Grześ (1653 m a.s.l.), to which the popular trail leads: 
Dolina Chocholowska (...) is the most appealing part of the Polish Tatra Mountains. The Dolina Chocholowska moutain hotel is arguably the most impressive. The views from Grzes (Mt.) are fantastic, spanning a 360 degree vista of the western Tatra Mountains. (BordRestaurant, Cameron Park, California, 5 *) - Chocholowska Valley

The second group of reviews contains the words: hors (e), carriag (e), beautus, peopl (e), crowd, trail, zlotus. It mainly concerns trips to Morskie Oko, during which many people take the opportunity to ride a horse-drawn carriage. This road is usually very crowded and tourists are forced to make many more unexpected charges for them (in PLN zlotys). Emotional experiences dominate here.

Overcrowded Tourist Trap. The whole experience is a bitter one, mostly because of the 10,000 visitors per day. You park $9 \mathrm{~km}$ away for 25 PLN. You pay 5 PLN to access the park. You pay 50 PLN to go up in a shabby smelly uncomfortable horse kart and 30 PLN for same trip back ... and you arrive at what sounds and look like an overcrowded municipal pool: too many people, too much noise, too many picnics. (Fred B., Nice, France, $2^{*}$ )—Morskie Oko

Morskie Oko is the most popular tourist destination in the Tatra. During the two holiday months, it is visited by up to 0.5 million tourists, which causes overcrowding and recreational conflict:

Crowds Spoil Everything. Unfortunately this quaint little town and the stunning mountain views are spoiled by the interminable traffic, the jams that come with it and the overwhelming number of people. The town center (Zakopane) is nothing more than a tourist trap-expensive shops and restaurants line the street and all you can see is the never-ending crowds of people in front, beside and behind you. (annal 335, Brantford, Canada, 2*)-Tatra Mountains

The accommodation and tourist emission center in the Tatra Mountains is Zakopane, a city with less than 30,000 inhabitants, where ca. 30,000 tourist accommodation places are officially registered in the Tatra district [53] and probably another 30,000 beds are provided unofficially [54]. This huge number of tourists in such a small area causes very emotional feelings in visitors. A lot of emotions are aroused by the view of horses pulling overloaded highlander carriages:

When you are walking up or down you constantly see the horses struggling to go up or down the path. It's animal cruelty at its finest. The horses had their tongues out, foam around their mouths and any individual could tell they were struggling. It was an unpleasant heart breaking sight. Before entering the park they have a sign that no more then 12 individuals should be on a carriage or it strains the horses. Of course almost every carriage we saw had more than 12! It was ridiculous! I wanted to quickly leave just because of how the horses were being treated. (Joselyn 715, Chicago, $3 *$ __ Black Pound

Despite the supervision that TNP exercises over the carriage of horse-drawn carriages, this situation is widely reflected in the media. Cases of horses falling from exhaustion are described, carriages with tourists are overloaded, animals quickly reach the slaughterhouse, because their price is relatively low compared to the revenues obtained by highlanders (górale) [55].

The next—-third-group of words includes: take, hour, walk, touris, entranc (e), park. Opinions containing these words relate mainly to descriptions of walking tours in the Tatra National Park. Cognitive experiences dominate here.

The city of Zakopane is a center from which tourists take buses to the outlet of the valleys, where the entrances to the National Park are located, with ticket outlets:

Entry to the valley at the very busy road junction in Kiry village. Entry tickets are sold here. There's a few junctions with other long distance trails, or there are short distance trail, of about $1 \mathrm{~h}$ each, that will let tourists explore some attractions on the side of the main course of the valley. (endrju_74, Ipswich, United Kingdom, 5 *)—Chocholowska Valley 
Admission tickets are moderate (2.5 PLN—approx. 0.5 EUR), and the carriage ride is significantly shortened by a rather monotonous march through the valley:

We took a bus from the centrum to Koscielisko. The Park is really lengthy to walk and there is an entrance fees which is very nominal. You can take horse cart if you are looking for a quick ride. Very nice view with lot of fresh air, caves, river streams. (Krishnakumar B, Michalowice, $4{ }^{*}$ )Kościeliska Valley

Some places in the Tatra are less frequented and require better physical condition. Black Pond is such a place, to which a steep trail from Morskie Oko leads:

This trip is a fantastic experience, the black pond (Czarny Staw, Fekete tó) is a hidden jewel of the Zakopane region. Besides this is a place which is horribly tough to reach but you do not need mountain climbing experience or an outstanding physical condition. The way is quite steep in some places and quite tiring. (975 Katalin, Varpalota, Hungary, 5 *)

The next group of opinions consists of the words: worth, recommend, quit, still, real, minute. They relate to the assessment of attractiveness and rank of tourist attractions visited (cognitive experiences).

For experienced mountain tourists who have visited the Alps, the Tatra Mountains may seem unattractive:

If you've traveled to other mountain ranges in the world, and seen their lakes, then Morskie Oko isn't worth the effort. If you're in the area, I'd recommend going, but to travel here form the Austrian or Swiss Alps, or even Slovenia, would be a bit of a let-down. (dacky2, Tromso, Norway, 3 *)

However, for other people, the same landscape seen from the road to Morskie Oko, despite the large number of people, is amazing and worth recommending:

Had a fantastic day hiking up to morskie oko, (.. ) the view was amazing and well worth it. It was fairly busy, quite a few people. Would definitely recommend this to everyone. (eloiseb113, Bournemouth, UK, $5^{*}$ )

The last group of opinions is dominated by words such as weather, earl (i) y, summer, start, before. These are recommendations on how to organize mountain hikes (cognitive experiences):

A walk trip to the famous Valley of 5 Ponds. It is exceptional experience. You would go the route to Morskie Oko pond - then when you will see Mickiewicz waterfall on the right you need to turn right and start ascending in beautiful Dolina Roztoki Valley. Check weather forecast before climbing Szpiglasowy. It is a bit demanding route. (Michal M, Warsaw, Poland, 5 *)

One of the most common tips that appear in this group is the need to check the weather forecast before going to the mountains and start the trip early in the morning:

The hike in normal weather conditions can be done in about 4, $5 \mathrm{~h}$. We started our hike a little before 9 am and it was already like a highway to Rysy, so I recon, the best experience would be to start the hike around 7 am or even a little bit earlier. (jurgisk_lv, Grobina, Latvia, $4^{*}$ )

\subsection{Identification of the Most Common Experiences in Opinions-Quantity Analysis}

In order to identify opinions in which words related to experiences appeared, a procedure of coding opinions was carried out. Packer and Ballantyne [44] and Packer, Ballantyne and Bond [56] distinguished 15 dimensions of experiments which they then characterized using different words. The authors of the article used these words to identify the experiences described by the authors of the opinions. Then, the coding procedure was started. The KH Coder software searched for the appropriate words (content of visitor experiences) and then assigned them to individual dimensions of visitor experiences (Table 3). 
Table 3. Frequency of codes $(\mathrm{N}=625)$.

\begin{tabular}{|c|c|c|c|}
\hline Dimensions of Visitor Experiences & Content of Visitor Experiences & $\mathbf{N}$ & $\%$ \\
\hline Physical_activity & activ|mobil|vigoro|energet|physical|climb|visit|walk|hike & 516 & 82.56 \\
\hline Excitement & excit|exhilarate|enthusiast|enjoyment|elation|enjoi|stun|fun|amuse|indulgem|breathtak & 12 & 1.92 \\
\hline Aesthetic appreciation & aesthetic|appreciation|beauty|grandeur|senses|beauti|beautus & 44 & 7.04 \\
\hline Peacefulness & peacefull|serene|relax|refresh|restore|quit & 18 & 2.88 \\
\hline Togetherness & sociable|togetherness|fellowship|companionship|community & 1 & 0.16 \\
\hline Spiritual engagement & spirit|reverent|worship|sacred & 4 & 0.64 \\
\hline Attention & attentive|alert|observant|concentration|mental & 1 & 0.16 \\
\hline Fascination & fascinated|amaz|intrigue|wonder|imagin & 6 & 0.96 \\
\hline Privilege & privilege|honor|fortunat|grateful|respect & 3 & 0.48 \\
\hline Compassion & concerne|compassion & 0 & 0.00 \\
\hline Reflective engagement & reflective|thoughtful|introspective|thought|ponder & 5 & 0.80 \\
\hline Connection & connection|attachment|nostalgia|nature|love & 84 & 13.44 \\
\hline Autonomy & independent|confident|choice|control|deciding & 12 & 1.92 \\
\hline Personal_growth & accomplishment|fulfillment|growth|self-discovery|self-actualization & 2 & 0.32 \\
\hline Tension & tense|frustrated|stress|overload|uncomfortabl|crowd & 103 & 16.48 \\
\hline No codes & & 68 & 10.99 \\
\hline
\end{tabular}

Source: Packer and Ballantyne (2016), Packer, Ballantyne and Bond (2018) and own research. 
Most opinions (82.45\%) contained words related to the experiences of physical activity. These are both descriptions of trips around the valleys "easy road, you are just walking, looking around" (Nastya_Lampy, St. Petersburg, Russia, $5^{*}$ ), as well as mountain climbing on the demanding trails "some parts were very steep. Climbing up took $30 \mathrm{~min}$ " (specas, Lithuania, 5 *).

Another group of experiences is tension, which appears in $16.48 \%$ of opinions. Both approach roads ("road asphalted road and very crowded", Maikel 1989, Ghent, Belgium, 3*), shelters ("Tee-house it was really crowded", erzs_betp, Szeged, Hungary, $5^{*}$ ) and surroundings of ponds ("Lake is nice, but too crowded ", Maikel 1989, Ghent, Belgium, 5*," The number of people hiking in this area is phenomenal! We have never seen so many people (of all ages) walking in nature before! ", Carl_and_janelle, Queensland, Australia, $4 *$ ).

The third group is connection to nature experiences (13.44\%). ("Once you love nature, make this journey!", Tatimtch 8, Minsk, Belarus, 5 *, "Lovely fish to watch under the clear aqua water.", Jim H, Bath, UK, 4 * " water is so clear! We loved it, a really stunning area", RoboMc, Colchester, UK, 5 *).

Aesthetic appreciation experiences were identified only in 44 reviews (7.04\%) ("large stones completely around the beautiful lake surrounded by mountain peaks", MichaelS, Boston, Massachusetts, $5 *$, "Still some magnificent views along the way", CM 9493, Scotland, $5 *$, "wow you with their natural grandeur", mekydro, Chertsey, United Kingdom, 5 *).

Other experiences were identified in less than $5 \%$ of opinions except for compassion, which was not found in any of the opinions.

\section{Discussion}

The analysis made it possible to identify the main topics of opinions about Tatra National Park in TripAdvisor reviews and experiences associated with communing with nature. The words related to the experiences of physical activity have a special advantage. This result confirms the role of the Tatra Mountains as the mountains in which active recreation is undertaken. This result is in line with the conclusions of Norma Polowitz Nickerson who noted that "activities engaged in" are frequently reported as the highlights of a travel experience. Importantly, the activities were intricately connected to the environment in which the activity took place [26] (229). This is due to the mountainous nature of the analysed area, where there are no other options than walking to reach the most interesting places (except for two routes that can be overcome by horse-drawn carriage). This area is quite different from the Danube Delta, for example, where physical activity in visitors' opinions was almost absent [45]. However, this was an exception because experiences of physical activity often accompany tourists in natural areas $[36,57,58]$. This result is also different from Kathleen Andereck's, Kelly S. Bricker, Deborah Kerstetter and Norma Polovitz Nickerson conclusions that tourists articulate three dimensions of meaning: the social aspects of the experience, the environmental aspects of the experience, and the aspect of activities within those environments as the experience [22] (p. 93).

However, there is doubt whether tourists who want to engage in physical activity must necessarily visit the area with the highest degree of nature protection. Those preferences do not indicate ecological awareness and it should be remembered that the purpose of creating National Parks is not only to make them available to the public, but also to educate, care for nature diversity and restore natural habitats [59]. The key to solving this problem may be analyzing the motivation of tourists and experience preferences. If preferences are more about active recreation and are not associated with the desire to explore the most valuable areas, tourists could spend time in less-endangered places than National Parks $[60,61]$.

Confirmation of these problems is another result of this analysis: the experience of tension is the second most frequently described group of experiences gained. This is the tension resulting from the crowd on access roads to shelters (to a lesser extent on mountain trails), as well as in Zakopane itself, which is described by tourists as a tourist trap. This phenomenon occurs especially often in natural areas near urbanized areas as well as near well known holiday resorts [62-64]. 
Despite the crowds, tension and overload, many tourists feel the connection with nature-this is the third largest group of identified experiences. Jan Packer and Roy Ballantyne [44] put them in a group of spiritual experiences as well as introspective experiences. Indeed, wildlife tourism has great potential to reawaken human connection with the natural world and can instill greater environmental awareness and a deep sense of wonderment $[36,39]$.

It can therefore be concluded that tourists notice crowding and relationships with nature, but the share of these associations in responses is six times less frequent than in the case of physical activity. It is amazing that experiences with aesthetic recognition make up only $7.04 \%$ of all associations. Aesthetic experiences are mentioned as dominant in nature tourism by many researchers [65-67]. Thus, the observation confirms that tourists who visit TNP for reasons of physical activity do not always attach importance to the beauty and uniqueness of the natural environment. This uniqueness was, after all, a source of tourism development in the studied area as early as the 19th century and constituted the basis for creating a protected area in Tatra. Based on the prevailing opinions, it cannot be concluded that tourists were interested in experiences resulting from a high level of ecological awareness.

Recommendations of tourists after the visit to the destination can also be treated as part of the assessment of their own experience. TNP visitors most recommended going on early trips to the mountains, checking the weather, and breaking away from the crowds besieging the most popular places. Some of them even recommended giving up attempts to visit TNP and go to the Slovak side of the Tatra Mountains. These recommendations, and especially the last of them, can be of great importance for the image of TNP, Polish Tatra Mountains and Zakopane and can significantly affect the decision of choosing a destination by other tourists $[68,69]$.

The analysed opinions lack experiences related to heritage interpretation, which, according to Gregory Benton [70] plays a key role in educating visitors, improving heritage protection, cultural respect and site promotion. These results contradict the findings of other authors [71-73]. This may be due to the nature of hiking in the Tatra: individual and not guided tours predominate there. Tourist trails in the TNP are very well marked and reaching almost all peaks does not require a tourist guide company. Nevertheless, TNP, together with the National Park on the Slovak side of the Tatra Mountains, are protected in form of UNESCO biosphere reserve (Man and Biosphere Program). The purpose of the UNESCO biosphere is to reserve is education, training and building regional identity [74]. According to the regulations of the National Park, highlanders who carry tourists on horse-drawn carriages are obliged to provide tourists with information on nature protection, history, ethnography, etc. However, this range of experiences is hardly visible in the opinions of visitors. This is because of the poor knowledge of foreign languages among highlanders, and the authors of the analysed opinions being mainly foreign-speaking tourists.

In this context (especially the building of regional identity by TNP), the lack of tourist experiences related to local culture, which is so strong in the Podhale region (highlander 'góral' folklore), is also striking. This is even more strange because highlanders transporting tourists with horse-drawn carriages must wear a regional outfit and use the highlander dialect [75]. It follows that the contact of tourists with highlanders is very superficial. Is it because the carriage ride, although implemented in traditional folk costumes, seems to them not very authentic? As indicated by studies by David Weaver [76] and Jennifer Chan and Tom Baum [57], local culture is an important motivational factor for ecotourists. Perhaps these encounters are realized while eating local dishes or listening to folk music in restaurants in Zakopane. However, the lack of these experiences, in the opinions of visitors, requires a deeper look at the quality of the interpretation of natural and especially cultural heritage in TNP. The authors assumed that reviews in TripAdvisor reflect the most important elements of the experience, but readers should be aware that the lack of references to ecological awareness in the descriptions is not proof that the person (who generates the content) does not have such an awareness. 


\section{Conclusions}

In tourism, an uncontaminated environment is very often the basis for creating a tourism product and determines the arrival of a tourist. Therefore, the level of ecological awareness of people using this environment is extremely important and should be reflected in the experience preferences and experiences gained.

Reviews on TripAdvisor indicate that the most important for visiting tourists were the experiences of physical activity $(82.45 \%)$. This confirms the trend of maintaining health and the desire to regenerate physical strength. It should be remembered that awareness of the importance of the environment for health and quality of life is not the same as protecting nature; tourists can take care of themselves and not wonder what effects the burden of the visited area brings.

The group of answers related to the connection to nature experiences is extremely small (14.44\%), which indicates that tourists probably did not come to TNP as a result of preferences related to ecological awareness. Some tourists feel tension (16.48\%), which indicates that the carrying capacity is exceeded [77]. A small group of opinions reflect experiences related to aesthetic appreciation experiences $(7.04 \%)$. TNP is a unique place with extremely valuable natural values and at the same time, one of the most crowded tourism destinations in Poland. Therefore, there is a need for activities related to ecological education and a search for ways to encourage active tourists to look for other places less sensitive to congestion. This can be a challenge for TNP managers. As stated by Richard Butler [27], national parks came into being with a more noble and inspiring purpose to protect areas of wild lands for a nation rather than for a privileged few, and at the same time, encouraging access to those areas by all those who can travel there.

Just being aware of the importance of the environment for health and quality of life is not the same as protecting nature, but it can be a starting point for deeper interest and broadening knowledge, which can ultimately translate into real environmental efforts.

This is in line with the results of the Aunkrisa Sangchumnong [78] study, which found that in environmentally valuable areas, the developing of sustainable tourism should take into account the education of the local community, which will bring beneficial effects for both this community and the environment.

One should also agree with Peter Weinberg [79], who showed that the experience profile should correspond to the unique nature of the area, and with Holly Donohoe and Roger Needham [80], who proved that the internet provides the primary mechanism for promoting ecotourism opportunities (providers) and for researching and planning ecotourism experiences (consumers).

Author Contributions: Conceptualization, A.N. and M.N.; methodology, A.N. and M.N.; software, A.N. and M.N.; validation, A.N. and M.N.; formal analysis, A.N. and M.N.; investigation, A.N. and M.N.; data curation, A.N. and M.N.; writing-original draft preparation, A.N. and M.N.; writing-review and editing, A.N. and M.N. All authors have contributed substantially to the work reported. All authors have read and agreed to the published version of the manuscript.

Funding: This research received no external funding.

Acknowledgments: The authors would like to thank Martins Balodis from Web Scrapper [https://www.webscraper. io/] for help in downloading reviews from TripAdvisor.

Conflicts of Interest: The authors declare no conflict of interest.

\section{References}

1. Ryan, C.H. From Motivation to Assessment. In The Tourist Experience; Ryan, C.H., Ed.; Cassel: London, UK, 1997; pp. 48-72.

2. Peter, J.P.; Olson, J.C. Consumer Behaviour and Marketing Strategy; Irwin: Boston, MA, USA, 1993.

3. Decrop, A. Destination choice sets-An inductive longitudinal approach. Ann. Tour. Res. 2010, 37, 93-115. [CrossRef]

4. MacCannell, D. The ego factor in tourism. J. Consum. Res. 2002, 29, 146-151. [CrossRef] 
5. Peters, M.; Weiermair, K.; Katawandee, P. Strategic brand management of tourism destinations: Creating emotions and meaningful intangibles. In Marketing Efficiency in Tourism; Keller, P., Bieger, T., Eds.; AIEST, Erich Schmidt Verlag: Berlin, Germany, 2006; pp. 65-80.

6. Richards, G. Creativity and tourism: The state of the art. Ann. Tour. Res. 2011, 38, 1225-1253. [CrossRef]

7. Davis, A. Experiential places or places of experience? Place identity and place attachment as mechanisms for creating festival environment. Tour. Manag. 2016, 55, 49-61. [CrossRef]

8. Pine, B.J.; Gilmor, J.H. The Experience Economy: Work Is Theatre E Every Business a Stage; Harvard Business School Press: Boston, MA, USA, 1999.

9. Weiermair, K. Neue Rahmenbedingungen der Indyvidualhotellerie und Gastronomie des 21. Jahrhunderts. In Unternehmertum im Tourismus, Fuhren mit Erneuerungen, 1st ed.; Weiermair, K., Peters, M., Pechlaner, H., Kaiser, M.-O., Eds.; Schmidt: Berlin, Germany, 2004; pp. 7-18.

10. Nowacki, M.; Niezgoda, A. Comparison of Poznań, Wrocław and Bratislava Image Attributes in the Reviews Published on TripAdvisor. Studia Perieget. 2019, 2, 63-77. [CrossRef]

11. Smith, W.L. Experiental tourism standards: The perceptions of rural tourism providers. Int. J. Serv. Stand. 2006, 2, 273-285.

12. Beeton, S.; Bowen, H.E.; Santos, C.A. State of Knowledge: Mass Media and Its Relationship to Perceptions of Quality. In Quality Tourism Experiences; Jennings, G., Nickerson, N., Eds.; Elsevier Butterworth-Heinemann: Burlington, MA, USA; Oxford, UK, 2006; pp. 25-37.

13. Butler, R. Volatile demand for tourism?-We can only market efficiently to what we know, rather than to what imagine. In Marketing Efficiency in Tourism; Keller, P., Bieger, T., Eds.; AIEST, Erich Schmidt Verlag: Berlin, Germany, 2006; pp. 13-22.

14. Driver, B.; Toucher, T. Toward a behavioral interpretation of recreational engagements with implications for planning. In Elements of Outdoor Recreation Planning; Driver, B.L., Ed.; University Microfilms: Ann Arbor, MI, USA, 1970.

15. Manfredo, M.J.; Driver, B.L.; Tarrant, M.A. Measuring Leisure Motivation: A Meta-Analysis of the Recreation Experience Preference Scales. J. Leis. Res. 1996, 28, 188-213. [CrossRef]

16. Manning, R.E. Studies in Outdoor Recreation: Search and Research for Satisfaction; Oregon State University Press: Corvallis, OR, USA, 2010.

17. Buchmann, A.; Moore, K.; Fisher, D. Experiencing film tourism. Authenticity \& Fellowship. Ann. Tour. Res. 2010, 37, 229-248. [CrossRef]

18. Cayne, B.S.; Bolander, D.O. The New Lexicon Webster's Encyclopaedic Dictionary of The English Language; Deluxe Edition; Cayne, B.S., Ed.; Lexicon Publications: New York, NY, USA, 1991.

19. Cohen, E.A. Phenomenology of Tourist Experiences. Sociology 1979, 13, 179-201. [CrossRef]

20. Antón, C.; Camarero, C.; Garrido, M.-J. Exploring the experience value of museum visitors as a co-creation process. Curr. Issues Tour. 2017, 21, 1406-1425. [CrossRef]

21. Jianyu, M.; Gao, J.; Scott, N. Introduction: Creating Memorable Experiences. In Visitor Experience Design; Scott, N., Gao, J., Ma, J., Eds.; CABI: Oxfordshire, UK; Boston, MA, USA, 2017; pp. 3-12.

22. Andereck, K.; Bricker, K.S.; Kerstetter, D.; Polovitz Nickerson, N. Connecting Experiences to Quality: Understanding the Meanings Behind Visitors' Experiences. In Quality Tourism Experiences; Jennings, G., Nickerson, N., Eds.; Elsevier Butterworth-Heinemann: Burlington, MA, USA; Oxford, UK, 2006; pp. 81-98.

23. Morgan, M.; Lugosi, P.; Ritchie, J.B. The Tourism and Leisure Experience: Consumer and Managerial Perspectives; Channel View Publications: Location, UK, 2010; Volume 44.

24. Dann, G.M. Tourist motivation an appraisal. Ann. Tour. Res. 1981, 8, 187-219. [CrossRef]

25. Iso-Ahola, S.E. Toward a social psychological theory of tourism motivation: A rejoinder. Ann. Tour. Res. 1982, 9, 256-262. [CrossRef]

26. Polovitz Nickerson, N. Some Reflections on Quality Tourism Experiences. In Quality Tourism Experiences; Jennings, G., Nickerson, N., Eds.; Elsevier Butterworth-Heinemann: Burlington, MA, USA; Oxford, UK, 2006; pp. 227-235.

27. Butler, R. Sustainable Tourism in Sensitive Environments: A Wolf in Sheep's Clothing? Sustainability 2018, 10, 1789. [CrossRef]

28. Tucker, H. Tourists and troglodytes. Negotiating for sustainability. Ann. Tour. Res. 2001, 28, 868-891. [CrossRef] 
29. Niezgoda, A. The role of environmental knowledge, attitudes and initiatives in the development of a tourism product. Tourism 2011, 21, 33-39. [CrossRef]

30. Higgins-Desbiolles, F. Indigenous ecotourism's role in transforming ecological consciousness. J. Ecotour. 2009, 8, 144-160. [CrossRef]

31. Canavan, B. Narcissism normalisation: Tourism influences and sustainability implications. J. Sustain. Tour. 2017, 25, 1322-1337. [CrossRef]

32. Fennel, D.A. Ecotourism, 4th ed.; Routlege Taylor \& Francis Group: London, UK; New York, NY, USA, 2015.

33. Mehmetoglu, M. Typologising nature-based tourists by activity-Theoretical and practical implications. Tour. Manag. 2007, 28, 651-660. [CrossRef]

34. Luo, Y.; Deng, J. The New Environmental Paradigm and Nature-Based Tourism Motivation. J. Travel Res. 2008, 46, 392-402. [CrossRef]

35. Kim, H.; Lee, S.; Uysal, M.; Kim, J.; Ahn, K. Nature-Based Tourism: Motivation and Subjective Well-Being. J. Travel Tour. Mark. 2015, 22, S76-S96. [CrossRef]

36. Curtin, S.; Kragh, G. Wildlife tourism: Reconnecting people with nature. Hum. Dimens. Wildl. Int. J. 2014, 19, 545-554. [CrossRef]

37. Csikszentmihalyi, M. Flow: The Psychology of Optimal Experience, 1st ed.; Harper Perennial: New York, NY, USA, 1991.

38. DeMares, R.; Krycka, K. Wild-animal-triggered peak experiences: Transpersonal aspects. J. Transpers. Psychol. 1998, 30, 161-177.

39. Bulbeck, C. Facing the Wild: Ecotourism, Conservation, and Animal Encounters; Earthscan: London, UK, 2005.

40. Pietrzak-Zawadka, J.; Zawadka, J. Forest therapy as a form of medical tourism. Ekonomia i Środowisko 2015, 4, 199-209.

41. Ohe, J.; Ikei, H.; Song, C.; Miyazaki, Y. Evaluating the relaxation effects of emerging forest-therapy tourism: A multidisciplinary approach. Tour. Manag. 2017, 62, 322-334. [CrossRef]

42. Ivens, S. Forest Therapy; Little Brown Book Group: London, UK, 2018.

43. Hill, J.; Curtin, S.; Gough, G. Understanding tourist encounters with nature: A thematic framework. Tour. Geogr. 2014, 16, 68-87. [CrossRef]

44. Packer, J.; Ballantyne, R. Conceptualising the visitor experience: A review of literature and development of a multifaceted model. Visit. Stud. 2016, 19, 128-143. [CrossRef]

45. Stoleriua, O.M.; Brochadob, A.; Rusua, A.; Lupua, C. Analyses of Visitors' Experiences in a Natural World Heritage Site Based on TripAdvisor Reviews. Visit. Stud. 2019, 22, 192-212. [CrossRef]

46. Skawiński, P. Tourism management in the Tatra National Park. Folia Tur. 2010, 22, 25-34.

47. Siarzewski, W. Tatrzański Park Narodowy; Wydawnictwo TPN: Zakopane, Poland, 2005.

48. Tatra National Park-Poland.pl. Available online: https://polska.pl/tourism/national-parks/tatra-nationalpark/ (accessed on 14 November 2019).

49. TripAdvisor: Read Reviews, Compare Prices \& Book. Available online: Tripadvisor.co.uk (accessed on 10 April 2019).

50. UK Press Center|About TripAdvisor. Available online: https://tripadvisor.mediaroom.com/uk-about-us (accessed on 16 September 2019).

51. Web Scraper-The \#1 Web Scraping. Available online: https://www.webscraper.io/ (accessed on 20 May 2019).

52. Fruchterman, T.M.J.; Reingold, E.M. Graph Drawing by Force-directed Placement. Softw. Pract. Exp. 1991, 21, 1129-1164. [CrossRef]

53. Statistics Poland-Local Data Bank. Available online: https://bdl.stat.gov.pl/ (accessed on 10 November 2019).

54. Zakopane: 22 tys. Legalnych Miejsc Noclegowych i 28 tys. Nielegalnych? Available online: http://www.tur-info. pl/p/ak_id,22478,,zakopane,w_zakopanem,tatry,sylwester,noclegi,miejsca_noclegowe,dziennik_polski.html (accessed on 25 November 2019).

55. Sikora, K. Rzeźnicy Znad Morskiego Oka. Górale Zamęczają Konie, a Turyści są za to Odpowiedzialni. 2013. Available online: https://natemat.pl/71015,rzeznicy-znad-morskiego-oka-gorale-zameczaja-konie-a-turyscisa-za-to-odpowiedzialni (accessed on 20 November 2019).

56. Packer, J.; Ballantyne, R.; Bond, N. Developing an Instrument to Capture Multifaceted Visitor Experiences: The DoVE Adjective Checklist. Visit. Stud. 2018, 21, 211-231. [CrossRef]

57. Chan, J.K.L.; Baum, T. Ecotourists' perception of ecotourism experience in Lower Kinabatangan, Sabah, Malaysia. J. Sustain. Tour. 2007, 15, 574-590. [CrossRef] 
58. Markwell, K. An intimate rendezvous with nature'? Mediating the tourist-nature experience at three tourist sites in Borneo. Tour. Stud. 2001, 1, 39-57. [CrossRef]

59. Formy Ochrony Przyrody. Available online: http://geoserwis.gdos.gov.pl/formy-protect-nature (accessed on 22 March 2019).

60. Butler, R.; Boyd, S. Tourism and National Parks. Issues and Implication; John Wiley \& Sons: New York, NY, USA, 2000.

61. Frost, W.; Hall, M. Tourism and National Parks: International Perspectives on Development; Routledge: London, UK; New York, NY, USA, 2009.

62. Puczko, L.; Ratz, T. Tourist and Resident Perceptions of the Physical Impacts of Tourism at Lake Balaton, Hungary: Issues for Sustainable Tourism Management. J. Sustain. Tour. 2000, 8, 458-478. [CrossRef]

63. Wahyuningputri, R.A. Ancol Jakarta Bay City as a sustainable destination park: Assessing crowd based on tourism carrying capacity. WIT Trans. Ecol. Environ. 2012, 161, 217-229. [CrossRef]

64. Chrobak, A. Geotourism in the Podhale Region as an opportunity to reduce the tourist overpopulation in the Polish part of the Tatra Mountains. In GEOTOUR E IRSE; Štrba, L., Ed.; Technical University of Košice: Košice, Slovakia, 2014; pp. 181-197.

65. Farber, M.E.; Hall, T.E. Emotion and environment: Visitors' extraordinary experiences along the Dalton Highwayin Alaska. J. Leis. Res. 2007, 39, 248-270. [CrossRef]

66. McDonald, M.; Wearing, S.; Ponting, J. The nature of peak experiences in wilderness. Humanist. Psychol. 2009, 37, 370-385. [CrossRef]

67. Pearce, J.; Strickland-Munro, J.; Moore, S.A. What fosters awe-inspiring experiences in nature-based tourism destinations? J. Sustain. Tour. 2016, 25, 362-378. [CrossRef]

68. Xiang, Z.; Gretzel, U. Role of social media in online travel information search. Tour. Manag. 2010, 31, 179-188. [CrossRef]

69. Bigne, E.; Andreu, L.; Hernandez, B.; Ruiz, C. The impact of social media and offline influences on consumer behaviour. An analysis of the low-cost airline industry. Curr. Issue Tour. 2018, 21, 1014-1032. [CrossRef]

70. Benton, G. Visitor perceptions of cultural resource management at three national park service sites. Visit. Stud. 2011, 14, 84-99. [CrossRef]

71. Munro, J.K.; Morrison-Saunders, A.; Hughes, M. Environmental Interpretation Evaluation in Natural Areas. J. Ecotour. 2008, 7, 1-14. [CrossRef]

72. Breakey, N.M. Studying World Heritage Visitors: The Case of the Remote Riversleigh Fossil Site. Visit. Stud. 2012, 15, 82-87. [CrossRef]

73. Madin, E.M.P.; Fenton, D.M. Environmental Interpretation in the Great Barrier Reef Marine Park: An Assessment of Programme Effectiveness. J. Sustain. Tour. 2004, 12, 121-137. [CrossRef]

74. MaB. Available online: https://tpn.pl/poznaj/mab (accessed on 22 November 2019).

75. Zarządzenie nr 7/2018 Dyrektora Tatrzańskiego Parku Narodowego z 19 Kwietnia 2018 Roku. Available online: https://tpn.pl/upload/filemanager/janczy/Zarzadzenie_7_2018_w_spr_regulaminu_przewozow_M_ Oko\%20.pdf (accessed on 19 November 2019).

76. Weaver, D.B. Hard-core ecotourists in Lamington National Park in Australia. J. Ecotour. 2002, 1, 19-35. [CrossRef]

77. Fisher, A. Sustainable Tourism. From Mass Tourism Towards Eco-Tourism; Haupt Verlag: Bern, Switzerland, 2014.

78. Sangchumnong, A. Development of a sustainable tourist destination based on the creative economy: A case study of Klong Kone Mangrove, Community, Thailand. Kasetsart J. Soc. Sci. 2019, 40, 642-649. [CrossRef]

79. Weinberg, P. Erlebnismarketing; Franz Vahlen: Munchen, Germany, 1993.

80. Donohoe, H.M.; Needham, R.D. Internet-based Ecotourism Marketing: Evaluating Canadian Sensitivity to Ecotourism Tenets. J. Ecotour. 2008, 7, 15-43. [CrossRef]

(C) 2020 by the authors. Licensee MDPI, Basel, Switzerland. This article is an open access article distributed under the terms and conditions of the Creative Commons Attribution (CC BY) license (http://creativecommons.org/licenses/by/4.0/). 